\section{The integration challenge in Canadian regionalization}

\author{
O desafio da integração na regionalização: \\ o caso do Canadá
}

\section{El reto de la integración en la regionalización canadiense}

Gregory Marchildon 1

doi: 10.1590/0102-311X00084418

\begin{abstract}
In the 1990s, regionalization was introduced in Canada through administrative delegation in order to achieve a number of reform objectives, but among the most important was to improve the integration of services across diverse health sectors. Despite the failure of regionalization in fulfilling its promise of integration, regionalization still provides a foundation for achieving system-wide integration. For this to occur, however, regional and provincial health authorities need to be given the effective accountability for primary care. Given that primary healthcare physicians provide the majority of primary care in Canada, the funding for primary care physicians should be returned from provincial ministries of health to regional (or provincial) authorities in order to allow them the opportunity to become responsible for coordinating health services for their patient populations across the continuum of care, and to contract providers with the necessary incentives and penalties.
\end{abstract}

Regional Health Planning; Systems Integration; Health Systems

\section{Correspondence}

G. Marchildon

Institute of Health Policy, Management and Evaluation, University of Toronto.

155 College Street, Suite 425, Toronto, M5T 3M6, Canada. greg.marchildon@utoronto.ca

1 Institute of Health Policy, Management and Evaluation, University of Toronto, Toronto, Canada. 


\section{Introduction}

Canada is a politically decentralized federation with a correspondingly decentralized healthcare system ${ }^{1}$. This system can be conceived as a three-layer cake. At the base of the cake is universal health coverage for hospitals, physicians, diagnosis and inpatient drugs, which are medical necessities. These services are administered through single payer administrations run by ten provincial and three territorial governments under national standards established under the Canada Health Act supported by federal cash transfers to the provinces and territories. The second layer of the cake is made up of social care services, mainly facility-based long-term care and home care services, and targeted prescription drug coverage programs operated by provincial and territorial programs. There are no national standards and these services and coverage programs vary considerably per province and territory. The third layer is made up of privately financed services such as dental care, vision care, prescription drug coverage through (mainly) employment based private health insurance, complementary and alternative medicine, and private elder care assisted living 2 .

Due to different ownership and financing arrangements, these layers are highly segregated. In addition, services within each layer are often organized in separated silos. Although researchers and policy advisors have long recognized the benefits that would accrue from the integration and coordination of services across the healthcare continuum, numerous systemic governance and financing obstacles have impeded change. Regionalization, in particular the establishment of geographically defined regional health authorities (RHAs), were seen by many health system experts as the vehicle required to break this impasse. As arm's length public bodies created by provincial governments, the RHAs would have the mandate to manage across health sectors. They could own and directly manage the healthcare facilities as a system or be given the funding to coordinate the services through contracting with independent facilities and providers.

It would take the public debt crisis of the early 1990s before provincial governments implemented regionalization (Table 1). In 1997, nine Canadian provincial governments had passed laws to create RHAs in order to coordinate services across the continuum of healthcare. This was to be accomplished in two ways: through the ownership of facilities, especially hospitals; and through contracts with independent facilities and organizations.

The only province slow to join the regionalization bandwagon was Ontario, Canada's most populous province. The Ontario government waited until 2005-2006 before it created what it would call Local Health Integration Networks (LHINs) with a mandate to integrate and coordinate services contract instead of through ownership, contrary to the dominant model of regionalization in the rest of Canada 3.

Despite the differences in the Ontario model of regionalization compared to the rest of Canada, there was a general consensus that regionalization was the policy solution to improving health service integration and coordination. However, within a few years, governments began to realize that their structural reforms were not achieving the expected results. In 2005, the Government of Prince Edward Island, admittedly in a province with the smallest population and geography, eliminated its RHAs. More significantly, in 2008, the Government of Alberta, eliminated its nine RHAs in favour of a single provincial health authority 4 . Recently, three jurisdictions - Nova Scotia, Saskatchewan and the Northwest Territories - replaced their respective RHAs with a single provincial health authority.

This recent trend to replace RHAs with more centralized structures reflects a crisis of confidence by political decision-makers in the policy effectiveness of regionalization 5 . While these centralized structures potentially offer some economy in scale, scope and other advantages, a single provincial authority also has its disadvantages. These include adding extra hierarchical layers of management and reporting that can delay decision-making, removing the key decision-maker from local communities and centralizing them in a single head office, and reducing the autonomy of decision-making of the provincial health authority relative to the provincial ministry of health 4 . 
Table 1

Regionalization in Canada from implementation to 2018.

\begin{tabular}{|c|c|c|c|c|c|}
\hline Province (or territory) & $\begin{array}{c}\text { Year } \\
\text { implemented }\end{array}$ & $\begin{array}{c}\text { Number of RHAs } \\
\text { in first iteration } \\
\text { of regionalization } \\
\text { (second iteration in } \\
\text { parentheses) }\end{array}$ & $\begin{array}{c}\text { Number } \\
\text { of RHAs in } \\
2018\end{array}$ & $\begin{array}{c}\text { Name used for RHAs (with single } \\
\text { provincial or territorial health } \\
\text { authority in italics) }\end{array}$ & $\begin{array}{l}\text { Total population } \\
\text { of province in } \\
2017 \text { (thousands) }\end{array}$ \\
\hline British Columbia & 1997 & $52(5)$ & 5 & Health authorities & 4,817 \\
\hline Alberta & 1994 & $17(9)$ & - & Alberta Health Services & 4,286 \\
\hline Saskatchewan & 1992 & $33(13)$ & - & Saskatchewan Health Authority & 1,164 \\
\hline Manitoba & 1997 & $12(5)$ & 5 & RHAs & 1,338 \\
\hline Ontario & 2006 & 14 & 14 & Local health integration networks & 14,193 \\
\hline Quebec & 1992 & 18 & 18 & Regional health agencies & 8,394 \\
\hline New Brunswick & 1992 & 8 & 2 & RHAs & 760 \\
\hline Nova Scotia & 1996 & $4(9)$ & - & Nova Scotia Health Authority & 954 \\
\hline Prince Edward Island & 1993 & $6(4)$ & - & Health PEI & 152 \\
\hline Newfoundland and Labrador & 1994 & 4 & 4 & Health regions & 529 \\
\hline Northwest Territories & 1997 & 6 & - & $\begin{array}{l}\text { Territorial Health and Social Services } \\
\text { Authority }\end{array}$ & 45 \\
\hline
\end{tabular}

RHAs: regional health authorities.

Sources: Axelsson et al. 6, Marchildon 11 plus provincial and territorial government websites. Population estimates for July 1 st, 2017 , from Statistics Canada, table 051-0001 (https://www150.statcan.gc.ca/t1/tbl1/en/tv.action?pid=1710000501, accesed on 25/Abr/2018).

Note: the health systems in two northern territories - Yukon and Nuvavut - were never regionalized and therefore excluded from this table.

\section{The purposes of regionalization and the integration challenge}

Based on various official statements and reports, governments in Canada were attempting to achieve the following distinct objectives through regionalization 6: (1) integrate a broad range of health services across the healthcare continuum; (2) consolidate and rationalize hospital services to reduce costs; (3) shift emphasis and resources from downstream illness care to upstream prevention and health promotion; (4) decrease variation and improve service quality through more evidence-based practices; (5) decentralize resources to facilitate a better match with population needs; (6) decentralize decision-making to increase the potential for public input and participation in health system change and the allocation of resources; (7) increase accountability by having RHAs responsible for health system performance and outcomes to the health ministry as the overall steward and funder.

Each of these seven objectives deserves considerable elaboration but this article will focus on the first objective - better integration of the health-related needs of a population within a geographically defined area. Based on the literature, this can be done using one of the three modalities: hierarchy, market competition and networked collaboration and coordination. In reality, publicly financed health systems use combinations of all three. Regionalization in the Canadian context involved a shift from a largely uncoordinated system in which the state acted as a passive payer of providers to a health system in which the provincial governments more directly managed the organization of health delivery through administratively delegated RHAs.

Regionalization in Canada involves administrative and fiscal, but not political, delegation. In contrast to regions as organized in Denmark, Italy and Spain for example, Canadian health regions are not governments and regionalization reforms cannot be classified as political decentralization 5 . Moreover, in contrast to regional networks in Brazil, Canadian health regions have no governance arrangements with, or accountabilities to, local and municipal governments. In this sense, Canadian regions are more similar to the 20 district health boards in New Zealand 7 or the 15 local health districts in the state of New South Wales, Australia (NSW Government. Local health districts and specialty networks. http://www.health.nsw.gov.au/lhd/Pages/default.aspx, accessed on 25/Apr/2018). 
The dominant coordinating modality of regionalization in Canada has been hierarchical. Previously independent organizations, especially hospitals, have been disbanded, and the management of their assets placed under the control of RHA executives and their governance boards. The boards are appointed by provincial governments and the managerial scope of RHAs set by provincial law and the discretion of ministers of health. At the same time, a minority of hospitals - Catholic hospitals in Western Canada, for example - have kept their boards but work in collaboration with RHAs. Longterm care (LTC) facilities are more varied. RHAs both run their own LTC homes as well as work with non-profit, community-based organizations that provide services in return for global funding envelopes. These are largely coordination arrangements that are distinct from market-based arrangements based on competition. In fact, New Public Management techniques, including the internal market approaches adopted in England in the early 1990s, have had little influence in Canadian health systems 8 .

Indeed, the regionalization reforms of the 1990s led to an increase in public ownership and control - from mainly non-governmental, non-profit organizations to publicly owned and controlled RHAs. The one exception to this trend was Ontario, where the reforms almost a decade later did not involve a change in ownership. Instead, LHINs were expected to coordinate the activities of health organizations, including independent, non-profit hospitals, by holding the purse strings. Again, however, this was done through networked collaborative arrangements (in keeping with the use of the word "network" in LHIN) rather than through competitive contracting. However, the use of the word "integration" raises a number of issues for both the newer LHIN model and the older RHA model in Canada.

Originally, it was thought that regionalization was essential to integrate services across the continuum of health. However, after years of experience with regionalization, there is a genuine debate in Canada as to whether regionalization achieved this key objective. There are two contesting schools of thought. One is that regionalization was not essential to achieving integration. Drawing policy lessons from for Canada from the recent reform experience in the United Kingdom, for example, Gwyn Bevan argues that "the presence or absence of regions in a province is less important" 9 (p. 20) in overcoming health sector silos than the system of sanctions for failure and rewards for success.

However, in the Canadian context, unlike the United Kingdom which started with a great amount of hierarchical control through a single national health system (NHS), Canada had an extremely fragmented and private delivery system. Theoretically, after universal medicare was implemented in the late 1960s and targeted subsidies and coverage for social care and prescription drugs were introduced in the 1970s, ministries of health could have used contracts to sanction failure and reward success. In practice, however, regionalization may have been a necessary step for historical reasons. The central actors in the system - physicians - were largely protected from performance-based contracts as a result of the terms of agreement reached between the state and organized medicine that allowed medicare to be implemented - terms that have been almost impossible to change since the 1960s 10 .

In this sense, regionalization may have been a useful, even if not strictly necessary, first step in Canada to facilitate integration across health sectors. But it has been insufficient to achieve integration. Regionalization itself was truncated in that primary care budgets were never transferred to provincial RHAs and LHINs. From the beginning, due to the centralization of physician budgets in provincial ministries of health, RHAs and LHINs did not have a key tool to pursue integration 10,11. This was no minor omission. As Barbara Starfield 12 noted some time ago, effective primary care is a key element in any high performing health system largely because it is essential for the integration of services across the continuum of care. Here, the accountability of primary care providers is crucial to ensuring that patients - particularly those with complex health and social needs - can obtain the appropriate diagnostics, prevention services and downstream care and treatments in a timely fashion 13 .

It seems logical, therefore, that for RHAs or LHINs - or the more centralized provincial and territorial health authorities - to be effective, they must have clear accountability for integration, and this can only be achieved by having the ability to organize primary care in a manner that facilitates the coordination of services across the continuum of health. The point of comparison here is New Zealand, where the accountability for primary care is more clearly in the domain of the district health boards 7. Overall, New Zealand consistently ranks better on most of the Commonwealth Fund's health system performance indicators than Canada: for example, 22\% of adults in New Zealand 
compared to $30 \%$ of adults in Canada reported experiencing a problem with care coordination in the 2016 International Health Policy Survey ${ }^{14}$.

\section{Integration: what is required beyond regionalization}

Before determining what needs to be done beyond regionalization in Canada in order to achieve more effective integration, it is useful to delve deeper into the meaning of the word integration. The World Health Organization (WHO) defines integrated health services as "the organization and management of health services so that people get the care they need, when they need it, in ways that are user-friendly, achieve the desired results and provide value for money" 15 (p. 1).

When it comes to integration of services across health sectors, the macro level of system organization is critical. This can be achieved through any one - or even a combination - of modalities based on bureaucratic hierarchy, market-style competition or network-style collaboration and coordination. Whatever the chosen modality of stewardship, based on the experience in the United Kingdom, it should be accompanied by a clear accountability regime with effective sanctions for failure and rewards for success.

In a recent review of regionalization completed on behalf of the Canadian Foundation for Healthcare Improvement, the authors concluded with seven principles to make health regions the basis for high performing health systems in Canada 16 . I will comment on the five principles most relevant to regionalization. In each case, I will suggest a concrete reform that can be initiated in order to accelerate integration across health sectors. In the jurisdictions where RHAs have been replaced by single health authorities, the suggestions remain relevant except where otherwise indicated.

The first relevant principle is RHAs and LHINs should be managed as a results-driven health system. Provincial ministries should set realistic performance targets for RHAs and LHINs with explicit incentives for achieving goals and hard consequences for failing to meet them. These targets can be adjusted for the health needs and disparities of individual RHAs/LHINs. By the same token, RHAs/ LHINs could set goals for facilitating integration, falling largely on primary care organizations. In return, provincial ministries of health and RHAs/LHINs would ensure that primary care providers have the authority and resources to carry out this more ambitious mandate.

The second proposal is to strengthen wellness promotion and public health, including inter-sectoral actions and policies. This is the type of principle that is generally seen as self-evident in theory but extremely difficult to implement in practice. The challenge in the Canadian context is that RHAs and LHINs have no organic connection to local and municipal governments, yet these governments are critical in many public and population health interventions. However, if each provincial ministry of health encouraged its respective RHAs or LHINs to identify at least one public or population health intervention that requires collaboration with local governments within its defined geographic boundaries, this would at least work in the short term. Such an approach would be a little more difficult in jurisdictions with more centralized structures, but provincial health authorities also need to work effectively with local governments if progress is to be made on this principle.

The third principle is to ensure timely access to primary healthcare. To translate this into practice in the Canadian context requires: (1) patient rostering in primary care practices to set up a proper accountability relationship between providers and patients on the one hand, and between providers and the provincial government on the other; (2) the effective use of interoperable electronic health records by all providers in real time and ensuring that patients have an immediate right of access to their own records; and (3) encouraging primary care practices to provide 24 hours, 7-days a week coverage through appropriate incentives and penalties, with guarantees concerning same-day or next-day appointments.

The fourth principle is to involve physicians in clinical governance and leadership by working in partnership with RHAs and LHINs. The single most important way to turn this principle into practice is to transfer physician budgets to RHAs and LHINs (or to provincial health authorities in more centralized structures). The funding and the accountability contracts that would accompany the funding would require a real relationship to be forged, not merely a fair weather or public relations type of partnership. General practitioners and other primary care providers would have greater responsibil- 
ity for system management and leadership, but they would also be held accountable for the results through performance requirements.

The fifth principle is engaging citizens in shaping their individual health destinies and their regional health systems. Again, this is a laudable principle, but to turn it into effective action requires major changes. RHAs and LHINs could provide citizens with information on the quality outcomes of individual providers, provider organizations and hospitals. This would generate greater transparency and choice of provider and institutions, a more user-centred approach to stimulating higher quality and better performance 17 . RHAs and LHINs could also use public consultation and engagement efforts to help inform decisions on priorities and even long-term direction, an element that is generally weak or absent in delegated administrative systems as opposed to politically decentralized regions in countries such as Denmark, Italy and Spain.

\section{Conclusion}

Despite its failure to deliver integration in the past, regionalization nonetheless still provides a potential foundation for achieving system-wide integration. For this to occur, however, much still needs to be done. First, RHAs and LHINs will need to be given effective accountability for primary care.

Given that primary care physicians provide the majority of primary care in Canada, the funding for primary care physicians should be returned from provincial ministries of health to regional authorities in order to allow them the opportunity to contract with primary care providers using the necessary incentives, so that they become responsible for coordinating health services for their patient populations across the continuum of care. As the case of the United Kingdom also illustrates, they will also need to introduce effective penalties where primary care providers do not live up to their responsibilities as the coordinators of care. In jurisdictions where regionalization has been abandoned in favour of single provincial or regional health authorities, primary care budgets can be transferred from provincial ministries to health to these more centralized authorities.

Although changing the high-level governance of primary care is difficult because of the historic position of organized medicine, there have been exceptions in recent years. In the Northwest Territories, all physicians contract with the territorial health authorities for their remuneration and working arrangements. When the territorial health authorities were amalgamated into a single territorial health authority, this arrangement continued. And although physician funding was never transferred from the Ontario Ministry of Health and Long-Term Care to the LHINs, the LHINs have been given greater responsibility for primary care and care integration through a new Patient's First Act (2016). Through this Act, the Ontario government now requires at least some primary care organizations to be accountable for LHINs. These are perhaps small changes in the Canadian context, but they demonstrate the fact that change can be made. 


\section{Additional information}

ORCID: Gregory Marchildon (0000-0003-48982392).

\section{References}

1. Marchildon GP. Health care in Canada: interdependence and independence. In: Marchildon GP, Bossert TJ, editors. Federalism and decentralization in health care: a decision space approach. Toronto: University of Toronto Press; 2018. p. 43-70.

2. Martin D, Miller AP, Quesnel-Vallée A, Caron NR, Vissandjee B, Marchildon GP. Canada's universal health-care system: achieving its potential. Lancet 2018; 391:1718-35.

3. MacLeod H. Local health integration networks: build on their purpose. Healthc Manage Forum 2015; 28:242-6.

4. Duckett S. Regionalization as one manifestation of the pursuit of the holy grail. Healthc Pap 2016; 16:53-7.

5. Marchildon GP. The crisis of regionalization. Healthc Manage Forum 2015; 28:236-8.

6. Axelsson R, Marchildon GP, Repullo-Labrador JP. Effects of decentralization on managerial dimensions of health systems. In: Saltman RB, Bankauskaite V, Vrangbaek K, editors. Decentralization in health care. Maidenhead: Open University Press; 2007. p. 141-66.

7. Tenbensel T. Health system regionalization - the New Zealand experience. Healthc Pap 2016; 16:27-33.

8. Marchildon GP. Reforming health management in Canada. Health Law Can 2008; 29:915.

9. Bevan G. What can we learn from the UK's "natural experiments" of the benefits of regions? Healthc Pap 2016; 16:16-20.

10. Marchildon GP. Physicians and regionalization in Canada: past, present and future. Can Med Assoc J 2017; 189:E1147-9.
11. Marchildon GP. Regionalization: what have we learned? Healthc Pap 2016; 16:8-14.

12. Starfield B. Primary care: balancing health needs, services and technology. New York: Oxford University Press; 1998.

13. Leutz WN. Five laws for integrating medical and social services: lessons from the United States and the United Kingdom. Milbank Q 1999; 77:77-109.

14. The Commonwealth Fund. 2016 Commonwealth Fund International Health Policy Survey of Adults. http://www.commonwealth fund.org/interactives-and-data/surveys/inter national-health-policy-surveys/2016/2016international-survey (accessed on 25/Apr/ 2016).

15. World Health Organization. Integrated health services - what and why? Geneva: World Health Organization; 2008. (Technical Brief, 1).

16. Bergevin Y, Habib B, Elicksen-Jensen K, Samis S, Rochon J, Denis J-L, et al. Transforming regions into high-performing health systems toward the triple aim of better health, better care and better value for Canadians. Healthc Pap 2016; 16:34-52.

17. Rechel B, McKee M, Haas M, Marchildon GP, Bousquet F, Blümel M, et al. Public reporting on quality, waiting times and patient experience in 11 high-income countries. Health Policy $2016 ; 120: 377-83$. 


\section{Resumo}

Na década de 1990, a regionalização foi introduzida no Canadá através da delegação administrativa, a fim de realizar uma série de objetivos de reforma, entre os quais o mais importante era a melhoria dos serviços entre os diversos setores da saúde. Embora a regionalização tenha deixado de cumprir plenamente a promessa da integração, ainda serve como base para alcançar uma integração sistêmica. Para tanto, as autoridades sanitárias regionais e provincianas devem assumir a responsabilidade efetiva pela atenção primária. Uma vez que os médicos de atenção primária prestam a maioria dos cuidados primários no Canadá, o financiamento deles deve ser devolvido pelas secretarias de saúde das províncias para as autoridades regionais (ou provincianas) para que assumam a responsabilidade pela coordenação dos serviços de saúde para suas populações de pacientes em toda a rede de cuidados, além de realizar contratos com prestadores, com os incentivos e penalidades que se façam necessários.

Regionalização; Integração de Sistemas; Sistemas de Saúde

\section{Resumen}

En los años 1990, se introdujo la regionalización en Canadá mediante la cesión de competencias administrativas; el fin de la misma era un número de objetivos de reforma, pero entre los más importantes estaba mejorar la integración de los servicios de salud a través de diversos sectores. A pesar del fracaso de la regionalización para llevar a cabo su promesa de integración, consiguió proporcionar las bases para alcanzar la integración en todo el sistema. No obstante, para que esto ocurra las autoridades regionales y provinciales necesitan un sistema eficaz de rendición de cuentas en el ámbito de la atención primaria. Debido a que los médicos se encargan de la mayor parte de la atención primaria en Canadá, la financiación para la misma se debería transferir desde los ministerios de salud provinciales hacia las autoridades regionales (o provinciales), con el fin de permitirles la oportunidad de convertirse en responsables de coordinar los servicios de salud para su población de pacientes, a través del continuum del cuidado, así como para contratar a proveedores con los necesarios incentivos y sanciones.

Regionalización; Integración de Sistemas; Sistemas de Salud 